\title{
Dijital Platformların Yaratıcı Düşünce ve Eylem Haliyle Etkileşimine İlişkin Bir Sorgulama
}

\author{
Fidan Terzioğlu \\ Doktora Öğrencisi \\ Galatasaray Üniversitesi \\ Medya ve İletişim Çalışmaları Bölümü \\ fidanterzioglu@gmail.com \\ ORCID: 0000-0001-7543-4661
}

\section{An Investigation About the Interaction of Digital Plat- forms and States of Creative Thinking and Action}

\begin{abstract}
This paper investigates the interaction in digital platforms with our abilities of creative thinking and creative action. The first section thus reviews the essential qualities that reveal the states of creative thinking and action. The following sections discuss how digital platforms and the attention economy affect these qualities. The paper contends that the fundamental problem behind these effects does not arise from the technology per se, but from the worldview that leads the economic system, using this technology. The paper finally brings up for discussion the positions and the steps that can be taken in order for this worldview and this system to change.
\end{abstract}

Keywords: Digital platforms, creative action, creative thinking, attention economy, social media addiction, hate speech, fake news 


\section{Une enquête sur l'interaction des plateformes numériques et les états de pensée et d'action créative}

\section{Résumé}

Cet article examine comment les plateformes numériques affectent les capacités de pensée créative et d'action créative des utilisateurs. La première section résume les qualités essentielles observées dans les états de pensée créatrice et d'action. Les sections suivantes discutent les effets des plateformes numériques et de l'économie de l'attention sur ces qualités. Le document propose que le problème fondamental de ces effets ne survient pas de la technologie elle-même; il survient de la vision du monde derrière l'économie qui utilise cette technologie. Le document indique enfin les stratégies que nous pouvons utiliser et les mesures que nous pouvons prendre pour changer cette vision du monde et ce système.

Mots-clés : plateformes numériques, action créative, pensée créative, économie de l'attention, dépendance aux médias sociaux, discours de haine, fausses nouvelles

\section{Öz}

Bu makale, günümüzde işleyen biçimleriyle dijital platformların yaratıcı düşünce ve eylem imkânlarımızla etkileşimini sorguluyor. Bu amaçla ilk bölümde yaratıcı eylem halini ortaya çıkaran bazı önemli nitelikleri gözden geçiriyor. Sonraki bölümlerde dijital platformların ve dikkat ekonomisinin bu nitelikleri nasıl etkilediğini araştırıyor. Bu etkilerin arkasında yatan temel sorunun teknolojinin kendisinden değil, bu teknolojiyi kullanan ekonomik sistemi yönlendiren zihniyetten kaynaklandı̆̆ını savunuyor. Bu zihniyetin ve sistemin değişmesi için alabileceğimiz konumları ve atabileceğimiz adımları tartışmaya açıyor.

Anahtar Kelimeler: Dijital platformlar, yaratıcı eylem, yaratıcı düşünce, dikkat ekonomisi, sosyal medya bağımlılığı, nefret söylemi, sahte habercilik 


\section{Giriş}

2020 yılının Temmuz ayında yayımlanan bilgilere göre, bu tarihlerde dünya üzerinde 2.6 milyar kişi aktif olarak Facebook kullanıyor. ${ }^{1}$ Aynı tarihlerde, iki milyardan fazla kişi YouTube, iki milyardan fazla kişi de WhatsApp kullanıcısı. Instagram, TikTok, Snapchat ve Twitter kullanıcılarının sayıları da bu rakamlara yaklaşıyor. Sosyal ağ platformları olarak tanıdığımız bu iletişim ağları, zaman ve mekân mesafelerini ortadan kaldırmasa da, bu mesafelerin getirdiği bazı engellerin çevresinden dolaşmamızı sağlıyor. Bulunduğumuz noktadan dünyanın her köşesine ve milyarlarca kişiye ulaşabileceğimize, aynı anda o milyarlarca kişinin bu platformlara akıttığı sınırsız veriye erişebileceğimize inandırıyor bizi. Yaratıcı düşünce ve yaratıcı eylem yeteneklerimizin hayata geçmesi için, gezegeni paylaştığımız kişilerle dayanışma içinde, yaratıcı eylemler doğrultusunda yaşamak için mükemmel imkânlara kavuştuğumuzu düşünebiliyoruz zaman zaman. Öte yandan, bu platformlarda yaşadığımız deneyimler ve yayımlanan araştırmaların getirdiği bilgi, bu ümitleri ve inançları ortadan kaldırır nitelikte. Dijital platformların kişileri yakınlaştırmak yerine yalnızlaştırdığı; nefret söylemini, sahte haberciliği, benmerkezci tüketimciliği derinleştirdiği görülüyor, hissediliyor, tartışılıyor.

Illetişim ve dayanışma imkânlarımızı zenginleştirme vaadiyle ortaya çıkan bu platformlar, yalnızlaşmaya, nefret söylemine ve kutuplaşmaya nasıl yol açıyor? Yaratıcı düşünce ve eylem yönelimini desteklemesini beklediğimiz dijital platformlar, bu yönelimi nasıl ve ne yönde etkiliyor? Dijital platformların yaratıcı düşünce ve eylem yeteneklerimizle giriştiği etkileşimin altyapısında ideolojik, kültürel ve ekonomik bağlamda ne tür dinamikler işliyor? Önümüzdeki çalışma, bu soruların cevaplarını araştırmak üzere yola çıkıyor. Dijital platformların yaratıcı düşünce ve eylem imkânlarımızla etkileşimini, bu etkileşimin arkasındaki dinamikleri ve bu dinamiklerin içinde alabileceğimiz konumları tartışmaya açıyor.

\section{Yaratıcı Eylem Halinin Temel Nitelikleri}

Mihalyi Csikszentmihalyi, insanda yaratıclık olarak tanımlanan olguyu inceleyen önemli çalışmalarıyla tanınan bir psikolog, araştırmacı. Bu alanda gerçekleştirmiş olduğu araştırmalar ilk olarak 1975 'te yayımlandı. O günden bu güne çok sayıda kitabı ve yaklaşık 300 makalesi pek çok dile tercüme edilerek yaratıcılık alanındaki akademik araştırmalara yön verdi (Csikszentmihalyi, 2014a; 2014b; 2014c). Bu bölümde, Csikszentmihalyi'nin yaratıcılık alanındaki çalışmalarının önümüze serdiği, literatüre yön veren bazı önemli bulguları gözden geçireceğiz.

Csikszentmihalyi yaratıcı düşünce ve eylem halini, kişinin belirli bir konuda keşif halinde, yeni fikirler ve eylemler ortaya koyduğu durumlar olarak tanımlıyor. Sıradan insanların bu nitelikteki deneyimlerini incelerken, çeşitli alanlarda önemli başarılarıyla öne çıkan, yaratıcı olarak tanımlanan kişilerin deneyimlerindeki ortak nitelikleri belirlemekle işe başıyor. Bu araştırmaların çeşitli ortamlarda, çok sayıda

1 https://www.statista.com/statistics/272014/global-social-networks-ranked-by-number-of-users/ 
kişiyle sürdürülmesi sonucunda ortaya çıkan bulgulara göre, yaratıcı düşünce ve eylem halindeki kişilerde gözlenen ortak nitelikler şöyle sıralanıyor (Csikszentmihalyi 1996; 2014c):

Niyetin ve hedefin belirli olması. Yaratıcı düşünce ve eylem halindeki kişi, ne yapmak istediğini net olarak biliyor. Belirgin bir niyet ve hedef doğrultusunda düşünüyor ve hareket ediyor. Bedeni, zihni, sezgileri, duyguları bu niyete ve hedefe yönelmiş durumda. Belirli bir matematik problemini çözmek üzere düşünen bir bilim adamı, hastasını ameliyat etmekte olan bir cerrah, bir müzik parçasını en iyi şekilde icra etmek üzere tüm yeteneklerini kullanan müzisyen, bahçesindeki bitkilere gereken bakımı en iyi şekilde sağlamak için uğraşan bahçıvan örneklerinde olduğu gibi, yaratıcı düşünce ve eylem halindeki kişi ne yapmak istediğini, neyin peşinde olduğunu net biçimde biliyor. Gerçekleşmesini istediği niyetin ve hedefin gerektirdiği soruları sormak, bu soruların çözümlerini araştırmak ve bulduğu çözümleri en iyi şekilde uygulamak üzere zihnini, bedenini, sezgilerini, duygularını bir arada seferber ediyor.

Eylemlerin ișe yarayıp yaramadığına dair içsel farkındalık. Yaratııı düşünce ve eylem halindeki kişi, düşüncelerinin ve eylemlerinin amacına hizmet edip etmediğini içsel olarak değerlendirebildiği bir süreç içinde. Müzik parçasını icra eden müzisyen enstrümanından çıkan sesin doğru olup olmadığını, sesi duyduğu anda biliyor. Bir makale üzerinde çalışan akademisyen, okuduğu metnin araştırdığı konuya dair ne söylediğini net olarak değerlendirebiliyor. Yazarken kurduğu cümlelerin anlamını, değerini yoklayarak ilerliyor. Marangoz ustası, eline aldığı tahtanın amacına uygun olup olmadığını, tahtayı keserken izlediği açının doğru olup olmadığını biliyor. Yaratıcı düşünce ve eylem halindeki kişi, dışarıdan bir değerlendirmeye intiyaç duymadığı bir bütünlük duygusuyla ilerliyor.

Yetenekler ve karșılașilan zorluk arasındaki denge. Yaratıcı düşünce ve eylem halindeki kişinin yeteneklerinin, önündeki işin zorluklarıyla uyumlu düzeyde olması çok önemli. Eğer kişinin yetenekleri yapılacak olan işin fazlasıyla üstündeyse, yaratıcı bir eylemin ortaya çıkması için gereken dikkati ve özeni göstermeyebiliyor. Öte yandan, eğer gerçekleştirmek istediği işin zorluğu yeteneklerini fazlasıyla aşıyorsa, bu işin üstesinden gelemiyor. İdeal durumda işin zorluğu, kişinin yetkinliğini bir parça zorlayacak düzeyde olmalı. Eğer işin zorluk düzeyi kişideki yeteneklerin tümüyle harekete geçmesini gerektiriyorsa, yetkinliğin gelişmesi için ideal ortam oluşuyor. Bu koşullarda yaratıcı eylem halindeki kişinin yetkinliği adım adım gelişebiliyor. Bu dinamikler ve dengeler, kişinin belirli bir alanda yetkinlik kazanmak için artan zorluktaki işlerle adım adım yüzleşmesi gerektiğini ortaya koyuyor.

Dikkati odaklı bir sekilde sürdürebilmek, zamanla gelișen bir yeti. Yaratıcı eylem halindeki kişi, dikkatini odaklı bir biçimde kesintisiz olarak sürdürebiliyor. Eylemi gerçekleştirirken bu dikkati sürdürmek için de bir çaba gösteriyor. Niyetin belirliliği ve yapılan işin yolunda gidip gitmediğini değerlendirme gereksinimi, yeteneklerin engelleri aşmak üzere harekete geçirilmesini ve tüm dikkatin odaklı 
biçimde seferber edilmesini gerektiriyor. Yaratıcı eylemlilik halinde yıllar geçtikçe deneyim kazanan bir kişide, dikkati dağıtan etkenleri devre dışı bırakan bir algı mekanizması gelişiyor. Nörobilim alanındaki araştırmalar da, dikkati bu şekilde odaklı tutma yetisinin deneyimle geliştiğini, bu yetiyi kazanan kişilerin beyinsel fonksiyonlarında adım adım gerçekleşen bir dönüşüm süreci belirlendiğini ortaya koyuyor (Karwowski ve Kaufman, 2016).

Başarısızlık korkusu hissedilmiyor. Yaratıcı eylem halindeki kişi dikkatini yaptığı işin en iyi şekilde ilerlemesine odaklamış olduğu için, bu eylemin başarısızlıkla sonuçlanıp sonuçlanmayacağını düşünmüyor. Zihnini, bedenini, sezgi ve duygularını odaklanmış biçimde kullanırken, bu eylemin önceki ve sonraki aşamalarına yönelik bir kaygı hissetmiyor. Böylece, başarısızlık korkusunun dikkati dağıtan, duyguları karıştıran, zihni, bedeni, sezgileri zayıflatan etkilerine maruz kalmadan ilerleyebiliyor.

Benlik kaygısı siliniyor. Yaratıcı eylem halindeki kişi, başkalarının onu nasıl gördügünü, başkalarının kendisi hakkında ne düşündüğünü ya da düşünebileceğini önemsemiyor. Diğer insanlar tarafından beğenilmek ve saygı görmek için bir çaba göstermiyor. Arzusu, niyeti ve çabası yaptığı işe yönelmiş durumda. Benlik kaygısı hissetmiyor. Ancak bu sayede paradoksal bir biçimde, dikkati ve çabası kendine yönelik arzularla bölünmediği için, benlik sınırlarının genişlediğini, yaptığı işin kapsadığı geniş bir alana doğru ilerlediğini hissediyor. Diğer bir deyişle benlik duygusu, yaratıcı eylemin potansiyel etki alanıyla özdeşleşiyor. Benlik sınırlarındaki bu büyüme sayesinde, yaratıcı eylem halindeki kişinin algı yetenekleri ve görüş alanı da genişliyor.

Zaman algısı farklılașıyor. Yaratıcı eylem halindeki kişi, saatle ölçülen standart zaman algısından sıyrılıyor. Zaman algısındaki bu değişim beden ve zihin fonksiyonlarını, duygularını da etkiliyor. Bu sayede kişi bazı durumlarda saatlerce duraklamadan, yorulmadan aynı işe odaklanabiliyor. Bazı durumlarda da, çok karmaşık görünen, uzun sürede halledileceği düşünülen bir soruna birkaç dakika içinde çözüm bulabiliyor.

Eylem kendisi için gerçekleștiriliyor. Yaratıcı eylem halindeki kişi, yaptığı işin sonuçları ne olursa olsun, deneyimlediği eylemlilik halini başlı başına ödül olarak algılıyor. Diğer bir deyişle, sürecin kendisine değer veriyor. Yaratıcı eylemlilik halini bir sonuca ulaşmak için gerekli bir araçtan ibaret olarak görmüyor. Bu etkinlik alanının olanaklarını keşfetmek, bu süreç sırasında yetkinliğin adım adım gelişmesi, eylemin kendisini bir ödül haline getiriyor. Kişinin bu işi mutlulukla yapmasını, bu işin diğer insanlara sunduğu fayda ve güzelliğe tanık olmasını, bu süreci şükranla deneyimlemesini sağlıyor. Eylemler istenilen sonuçları getirmese bile, kişi bu süreci öğrenmek, keşfetmek ve deneyim kazanmak için kullanabiliyor. Yaratıcılık alanında yürütülen uzun süreli araştırmalara göre, kişi yaratıcı eylemle belirli bir alanda yetkinlik kazandıkça, sürecin değer kazandığı bu bütüncül deneyim, yaşamın diğer alanlarına da yayılıyor (Csikszentmihalyi, 2014a; Ryan ve Deci, 2018). 


\section{Narsistik Yönelim ve Yaratıcı Yönelim}

Csikszentmihalyi, yaratıcı eylem halindeki kişilerde görülen bu özellikleri ortaya koyarken önemli bir konuyu da gündeme getiriyor; narsistik eğilimlerden kaynaklanan başarı istencinin, yaratıcı eylem halinde görülen bu niteliklerden çok farklı nitelikler sergilediğini vurguluyor. (Csikszentmihalyi, 2014c, s. 195-207). Yaratıcılık alanında sürdürülen araştırmaların ortaya koyduğu bulgulara göre narsistik yönelimden kaynaklanan odaklıık hali, yaratıcı eylem halinde görülen odaklıık halinden çok farklı nitelikler gösteriyor. Bu farklııkları kısaca gözden geçirelim.

Narsistik yönelimdeki kişi, kendisine dair taşıdığı benlik algısındaki bir eksikliği diğer insanların hayranlığını, beğenisini ve saygısını kazanarak telâfi etmeye çalışıyor. Bu yönelimden kaynaklanan odaklılık halinde kişinin baskın hedefi, diğer insanların beğenisini kazanmak. Ancak diğer insanların beğenisini ne kadar kazansa da, bu kazanım kendi benliğine ilişkin eksiklik algısını değiştirmiyor. Bu durumda, başkaları tarafından beğenilme çabası kişiye istediği sonucu getirmeyen yıkıcı bir döngü oluşturabiliyor.

Narsistik yönelimdeki kişi için ortaya koyduğu düşüncelerin, eylemlerin içeriği ve sonuçları, kendisine beğeni kazandırmalarının dışında bir değer taşımıyor. Böyle bir kişi ortaya koyduğu düşünce ve eylemin başkalarının yaşamını nasıl etkilediğini, ortak yaşama ne getirdiğini önemsemiyor. Bu durumda dikkati sürekli kendi benliğine yönelik kaygılar ve düşünceler tarafından bölünüyor. Başarısızlık korkusu, beğenilmeme kaygısı düşüncelerini ve eylemlerini farklı yönlere doğru çekiyor. Henüz beğenisini kazanamadığı kişilerin ilgisi en değerli, en önemli, ancak daima belirsiz bir hedef olarak varlığını koruyor. Bu çaba sırasında kazandığı deneyim ve yetenekler bu kişiye istediği doyumu getirmiyor ve ortak bir yaşama katkı sağlamanın verebileceği mutluluğu hissedemiyor.

Buna karşılık, yaratıcı eylem halindeki kişinin çıkış noktası, yaşama yönelik bir merak ve keşif arzusu. Bu keşif yolculuğunda kişi, içinde bulunduğu ortak yaşamda diğer insanların o güne kadar oluşturduğu bilgi kaynaklarını, ortaya koyduğu yöntem ve teknikleri öğreniyor. Kendisinde bulduğu yetenekleri geliştiriyor ve bu yeteneklerle o bilgi kaynaklarına ve yöntemlere katkıda bulunuyor. Bu süreçte kişi başkalarının dikkatini toplamak için değil, kendi dikkatini ortaya çıkarmaya çalıştığı işe odaklamak için çaba gösteriyor. Bu çaba sırasında attığı adımlar her zaman istediği sonuçları getirmese de, yaşadığı deneyimi öğrenmek ve gelişmek üzere kullanabiliyor. Bu sırada edindiği yetenekler önündeki keşif yollarını zenginleştirirken, diğer insanlarla dayanışmaya ve dostluğa dayalı ilişkiler kurmasına imkân veriyor. Şükran ve hayret duygularından beslenen, ortak keşiflere dayalı zengin bir hayat deneyimine yol açabiliyor (Csikszentmihalyi, 2014a).

Csikszentmihalyi, yaşamın ilk yıllarında narsistik yönelimle ortaya çıkan başarı istencinin, kişilik gelişimi ve kazanılan deneyim sayesinde, yaratıcı yönelimin hizmetine girebildiğini de vurguluyor. Araştırmalar, böyle bir dönüşümün gerçek- 
leşebilmesi için, kişinin yaratıcı yönelimi destekleyen ve geliştiren bir ortamda büyümesinin birincil derecede önem taşıdığını ortaya koyuyor. Diğer bir deyişle narsistik yönelimi değil, yaratıcı yönelimi destekleyen, bu iki yönelim arasındaki farkı ayırt edebilen bir kültürde büyümek, bu kültürü besleyen bir ortamda yaşamak, kişideki yaratıcı yönelimin sürekliliği için çok büyük bir değer taşıyor. Öte yandan, yaşamın ilk yıllarında baskın olan narsistik yönelim, kişinin benmerkezciliği ve rekabetçiliği besleyen bir ortamda büyümesi ve böyle bir ortamda yaşamaya devam etmesi durumunda daha da güçlenebiliyor.

Yaratıcı yönelimi destekleyen ve besleyen bir ortamda yaşayan kişi, yaratıcı yönelimin gerektirdiği becerileri edinmek, geliştirmek ve sürdürmek için çok daha elverişli bir konumda. Kişilik gelişimine ilişkin diğer alanlarda olduğu gibi, yaratıcı yönelimin gelişmesi için de, diğer insanlarla güvene dayalı ilişkiler kurabilmek ve sürdürebilmek önemli bir değer taşıyor. Yaratıcı yönelimle deneyim kazanmış olan, rol modeli oluşturabilen, deneyimini birlikte yaşadığı kişilere aktaran farklı kişilerle ilişkide olmak, kişideki yaratıcı yönelimin güçlenmesi ve gelişmesi için önemli ve etkili bir dayanak oluşturuyor (Karwowski ve Kaufman, 2017; Richards ve Csikszentmihalyi, 2007, s. 25-55).

\section{Dikkat Ekonomisi}

Yaratıcı düşünce ve eylem alanındaki araştırmaların önümüze getirdiği bu bilgilerin ışığında, dijital platformlardaki dinamiklerin yaratıcı düşünce ve eylem imkânlarımızla etkileşimini incelemeye başlayabiliriz. Bunun için öncelikle, bu dijital platformları yürüten algoritmaların nasıl bir amaç ve yönelim doğrultusunda şekillendiğini gözden geçirmek gerekiyor.

Dijital ağların yaşamımıza girmeye başladığı ilk yıllarda, teknolojinin sağladığı bu iletişim altyapısının her kullanıcıya yeni özgürlük, ifade ve yaratııılık imkânları getirebileceğine inanılmıştı. Oysa bu iletişim ağlarının günümüzdeki işleyişi, öncelikli olarak tek bir amaca hizmet ediyor: Bu iletişim platformlarını elinde tutan şirketlerin reklâm gelirini ve kârlıığını arttırmak. İkibinli yılların başlangıcından itibaren, dijital platformların kurulum ve gelişim dinamiklerine bu öncelikli hedef yön verdi (Foroohar, 2019). Dijital platformlardaki dil, kültür ve iletişim dinamikleri her açıdan bu amaca hizmet eden yönlerde gelişti. Öyle ki, bugün ulaştığımız noktada kullanıcıdan ücret talep etmeyen bu sistemler, aslında kullanıcıya çok büyük bedeller yüklüyor (Lanier, 2019). Kullanıcının dikkatini avlayıp tutsak ederek dünya görüşünü şekillendiren, fikirlerine ve eylemlerine yön veren bir manipülasyon sistemi olarak gün geçtikçe etkinliğini arttırıyor. Ortak yaşamımızı her açıdan etkileyip dönüştüren, son derece derinden işleyen bir mekanizmayla dijital platformlardaki tüm imkânları birkaç şirketin servetini ve gücünü büyütmek üzere kullanıyor (Bridle, 2019; Foroohar, 2019).

Bu alanda gerçekleştirilen bazı tartışmalar, dijital platformlardaki bu mekanizmayı teknolojinin kaçınılmaz bir etkisi ve sonucu olarak kabul etme yanılgısı- 
na düşebiliyor. Oysa burada işleyen dinamiklerin sorumlusu, teknolojinin kendisi değil. Bu noktayı fark etmek, bu alandaki sorunları daha derinden kavrayabilmemiz ve bu sorunlara yaratıcı çözümler geliştirebilmemiz için yaşamsal bir önem taşıyor. Dijital platformları işleten teknoloji, onu şekillendiren ve kullanan insan topluluğunun amaçlarına hizmet ediyor. Bu teknolojiyi tekelinde tutan ve yönlendiren şirketler, öncelikle ve sadece kendi kârlııklarını gözetiyor (Bueno, 2017). Biz kullanııılar bu işleyişi kaçınılmaz olarak kabul edip böyle sürmesine izin verdiğimiz sürece, bu şirketler daha da güçlenebilir, manipülasyona dayalı bu ilişki sistemi, dil ve kültür derinleşebilir. Oysa dijital teknoloji ve bu teknolojiyi kullanan platformlar bireysel ve ortak yaşamlarımızın zenginleşmesine ve gelişmesine gerçekten hizmet edebilir. Ancak bu olasılığın gerçekleşebilmesi için, bireysel ve toplu bir uyanışa ve dönüşüme intiyacımız var. Bu uyanışın harekete geçmesi ve bir dönüşüme yol açması için, öncelikle bu manipülasyon sisteminde dikkatimizin, irademizin ve perspektifimizin nasıl tutsak edildiğini, yaratıcı düşünce ve eylem yeteneklerimizin nasıl engellendiğini fark etmemiz gerekiyor.

Sosyal ağ platformlarını işleten yapay zekâ algoritmaları, her birimizin dijital ortamda bıraktığı her izi kaydediyor. Arama motorlarında kullandığımız sözcükler, önümüze çıkan seçenekler arasında yaptığımız tercihler, karşılaştığımız durumlar karşısında gösterdiğimiz tepkiler; duygularımız, davranışlarımız ve eylemlerimiz sürekli kayıt altına alınıyor. Günlük yaşamımızda dijital ağları kullandığımız her etkinlikte, bu verilere yenileri ekleniyor. Nabız ölçen, adım sayan, tansiyon ölçen, konum belirleyen algoritmalar, otomobilimizin internete bağlı verileri, içinden geçtiğimiz ve içinde yaşadığımı ortamlar, cep telefonumuzun bedenimize ve zihnimize ilişkin kaydettiği tüm veriler bu izleri her saniye çoğaltıyor ve bu veriler hiçbir şekilde silinmiyor. Her birimizin kimlik bilgileri, yaşı, cinsiyeti, mesleği, eğitimi, alışveriş harcamaları, ilgi alanları, ilişki kurduğu kişiler, ilişki kurmak istemediği kişiler, ilişkilendiği kişilerin kimlik verileri, iletişim için kullandığı tüm ifadelerle birlikte kalıcı olarak kayıtlara geçiyor (Zuboff, 2019, s. 130-133). Bu bilgilerin gün geçtikçe çoğalması ve büyümesi, bu bilgilerin toplamını kullanarak davranışlarımızı öngörmek üzere çalışan yapay zekâ algoritmaları için çok önemli. Çünkü bu bilgilerin toplamı büyüdükçe ve zenginleştikçe, algoritmaların bireysel ve toplu davranışlarımızı öngörme yetenekleri gelişiyor. Davranışlarımızı öngörmek ve manipüle etmek üzere işleyen bu algoritmalar, bu işi daha etkin yöntemlerle gerçekleştirmek üzere kendi kendilerini geliştiriyor. Tüm bu etkinliğin hedefi belirli: Kullanıcının dikkatini avlayabilecek içeriklerin profilini belirlemek ve bu profilin dijital platform şirketine maksimum gelir getirecek biçimde reklâmverenlere satılmasını sağlamak. Bu sistemde kullanıcı dijital platformda ne kadar uzun süre kalırsa, şirkete o kadar fazla gelir getiriyor. Dolayısıyla yapay zekâ algoritmaları, kullanııının dikkatini tutsak etmenin en iyi yöntemlerini bulmak üzere işliyor. Kullanıcı havuzuna kaydedilen bilgiler çoğaldıkça, dikkati avlamanın daha ince yöntemleri gelişiyor; böylece tüm sistem kendi kendini eğiten yapay zekâ algoritmaları tarafından yönetiliyor (Williams, 2018).

Bu sistemde alınıp satılan mal, kullanıcıların dikkati, zamanı ve zihin yapısı. Bilindiği gibi, sosyal ağ platformlarındaki sayfa içeriklerini üreten kişiler de aynı kulla- 
nıcılar. Dolayısıyla bu sistemde ücret alarak çalışan işçiler değil, bedel ödeyerek ve gönüllü olarak çalışan işçiler söz konusu. Sosyal ağ platformlarını elinde tutan ve reklâm gelirini kazanan şirketler bu mekanizmayı yürütmek için, çok az sayıda çalışana ücret ödüyor. Bu çalışanlar da yapay zekâ algoritmalarının en etkin şekilde kullanılmasını, kullanıcı dikkatinin reklâmverenlere satımasını ve böylece kâr maksimizasyonunun devamlılı̆ını sağlamakla görevli. Şu anda dünyanın en zengin kuruluşları olan bu şirketler, dünyanın en prestijli ve güçlü eğitim kurumlarının mezunlarına en avantajlı ücret ve çalışma koşullarını sağlayarak istihdam etme olanağına sahip. Böylece, toplumdaki en yetenekli, en iyi eğitim almış insanlar, insanlığın geri kalanının dikkatini tutsak kılmak üzere işleyen bir mekanizmanın optimizasyonu için çalışıyor. Bu eğitimli ve yetenekli insanlar, insanlığın önündeki yaşamsal sorunların çözülmesi için çalışmıyor. Sürdürülebilir enerji kaynaklarının geliştirilmesi için, toplumdaki eşitsizliklerin dengelenmesi için, eğitim ve sağılı sorunları için, insandaki yaratıcı yeteneklerin gelişmesi için çalışmıyor. Kullanıcıların yaratııı eylemlerde bulunmak için ihtiyaç duyduğu içsel dikkati, amaçıı̆ı̆ı ve iradeyi tutsak eden algoritmaların sürekliliğine hizmet ediyor (Eubanks, 2019; Noble, 2018; Zuboff, 2019).

\section{Yaratıcı Eylem için Gereken Dikkatin Manipülasyonu}

Illk bölümde de gördüğümüz gibi, yaratıcı eylem halinin öncelikli koşulu, kişinin dikkatinin belirli bir konuda odaklı kalabilmesi. Bu dikkatin belirli bir niyet doğrultusunda, bir amaçlılık halinde kullanılması. Kişinin neyi, neden yaptığının farkında olmak üzere dikkatini odaklı tutması. Ancak gördüğümüz gibi, dijital platformların algoritmaları bu dikkati dağıtmak ve tutsak kılmak üzere çalışıyor. Kullanıcıya hangi durumda hangi içeriği sunarsa davranışını istenen yönde etkilediğini öğrenen bir sistem bu. (Galloway, 2018). Bu zincire maruz kalan kullanıcl, eğer çok bilinçli ve iradeli değilse, önüne serilen içeriklerin, videoların, yazıların, seslerin, renklerin etkisine kapılıyor. Tam olarak o andaki ruh halini manipüle etmek üzere oluşturulan zincire kapılıp sürüklenmemek için olağanüstü bir kararlıık göstermesi gerekiyor (Wu, 2016). Aksi halde, belirli bir niyet doğrultusundaki yaratıcı eylem hali için sürdürmek zorunda olduğu dikkat, yapay zekâ algoritmaları tarafından emilip yok ediliyor.

Dikkati odaklı biçimde sürdürme yetisinin yıllar içinde gelişen bir yetenek olduğunu söylemiştik. Eğer bu yeteneği henüz gelişmemişse ya da bu yeteneğini uzun süre kullanmazsa, kişi sosyal ağ platformlarının dikkat emici dinamiklerine bağımlı hale gelebiliyor. Bu nedenle, sosyal medya bağımlılığı akademik literatürde hızla büyüyen bir araştırma alanı oluşturmuş durumda. (Kuss ve Griffiths, 2011; Andreassen, 2015). Sosyal medya kullanımını bağımlııı oluşturarak ruhsal dengesizliklere yol açan bir olgu olarak inceleyen önemli araştırmalar yayımlandı. (Kuss ve Griffiths, 2017; Alter, 2018) Bu araştırmalar sosyal medya bağımlılığının kişinin organizmasında herhangi bir fiziksel madde bağımlılı̆ından çok daha derin bir etkiye yol açabildiğini gösteriyor. Bunun nedeni dijital platformları yöneten algoritmaların beyindeki haz ve endişe reseptörlerini hedef alması. Dikkati avlamak için, kişinin belli bir anda haz ya da endişe hissetmesini sağlayabilecek içerikleri 
birbiri ardına, zincirleme olarak önüne sermesi. Kişi bu zincire kapıldıkça ve daha fazla zamanını bu döngüde geçirdikçe, beyinsel fonksiyonlarındaki dinamikler dönüşüme uğruyor. Haz ve endişe itkileri üzerinde irade sahibi olmaktan giderek uzaklaşıyor (Alter, 2018, s. 68-89). Haz ve endişe itkilerine söz geçiremeyen, dikkatinin kontrolünü kaybeden kişi, yaşama dair içten içe sürdürdügü daha büyük hedefleri ve niyetleri gerçekleştirme gücünü kendisinde bulamıyor. Özgüvenini ve öz saygısını yitiriyor. Yaratıcı düşünce ve eylem için kullanabileceği yetenekleri harekete geçiremiyor. Bu yeteneklerin farkında olsa bile, onları kullanma iradesini ve kararlıı̆̆ını gösteremiyor. Kendisindeki içsel bilgi ve dayanaktan uzaklaşıyor, kendisine dair süregiden bir başarısızlık duygusuna kapılıyor. Kendisine ilişkin taşıdığı benlik algısı, dijital platformlarda kendisine aşılanan kimlik tanımlarının sınırlarına mahkûm oluyor (Lanier, 2010; Carr, 2011).

Oysa yaratıcı düşünce ve eylem, kişinin kendi dikkatini, haz ve endişe itkilerini yönlendirebilmesiyle mümkün olan bir etkinlik hali. Hayatın ilk yıllarında, henüz kişiliğin gelişmediği yaşlarda, insanın bu itkiler üzerinde irade sahibi olması mümkün değil. Ancak zamanla, kişinin yetileri geliştikçe, haz ve endişe itkilerini denetleme becerisi ortaya çıkabiliyor. Bunun için de, öncelikle kişinin dikkatini odaklamayı öğrenmesi gerekiyor. Bu dikkati uzun vadeli amaçlar doğrultusunda kullanırken haz ve endişe itkilerini yönlendirme becerisi gelişiyor (Vartanian vd., 2016). Yaratıcı eylemlilik, kişinin gerektiğinde can sıkıntısına, hayal kırıklığına, rahatsızlığa, endişeye tahammül etme becerisiyle birlikte gelişen bir yetenek. Bu becerinin gelişebilmesi için, kişinin içinde yaşadığı ortamın böyle bir beceriyi desteklemesi, en azından örselememesi gerekiyor. (Csikszentmihalyi, 2014a). Oysa sosyal ağ platformlarındaki dil, kültür ve dinamikler bu beceriyi desteklemek üzere değil, endişe veren mesajları ve sahte haz vaatlerini çoğaltmak üzere çalışıyor. Kişinin en ilkel dürtülerini tetiklemek ve manipüle etmek üzere, dikkatini tutsak etmek üzere işliyor (Jackson, 2018). Böylece dijital teknolojinin sağladığı tüm imkânlar, ortak yaşamımızdaki olağanüstü güç dengesizliklerini her geçen gün daha da derinleştiren amaçların hizmetinde kullanılıyor.

\section{Narsistik Yönelimi Güçlendiren Algoritmalar}

Dijital platformları elinde tutan şirketleri güçlendiren ekonomik sistem, kullanıcıların dünya görüşünü ve ilişki kurma biçimlerini derinden etkileyerek dönüştürüyor. Bu sistemin sarmalına tutsak olan kişi, kimliğini ve davranışlarını temellendirmek için başkalarından alacağı hayranlık ve beğenilme mesajlarına bağımlı hale geliyor. Özellikle genç kullanıcılarda çok ciddi sorunlara yol açan bu eğilim, yetişkin kullanıcıları da önemli ölçüde etkisi altına alabiliyor. Bu ilişki dinamiklerine bağlanan kişi narsistik yönelimin itkileriyle sürüklenerek yaratıcı yönelimden uzaklaşıyor; yaşamın önüne çıkardığı sorunlar ve fırsatlar karşısında yaratıcı çözümler geliştirerek öğrenme ve ilerleme imkânından yoksun kalıyor (Freitas, 2018).

Sosyal ağ platformlarında aktif olarak görünmek isteyen her kullanıcı, oluşturduğu içerikleri başkalarına göstermesini sağlayan bir profil, bir kimlik oluşturmak 
zorunda. Bu kimliğe dikkat çekmek ve beğendirmek için de sürekli bir çaba sarf etmesi gerekiyor. Bu çaba sırasında gerçeği söylemesi ve göstermesi beklenmiyor. Dikkati ve beğeniyi üzerine çektiği sürece, her türlü mesajı verebileceği, her şeyi gösterebileceği fikri geçerli. Böylece kullanııının zihin yapısı ve davranışı sistemin hedefine uyumlanıyor: "Dikkati avlayabildiğin sürece, sisteme dahilsin." Sistemin ve sürünün dışında kalma tehlikesi, başkalarının onayına intiyaç duyan narsistik yönelimdeki bir kişi için ölümle eş anlamlı bir tehlike olabilir. Böylece dijital platformlar, birbirini kopyalayarak narsistik yönelimi çoğaltan, benmerkezci, rekabetçi, kaygılı, dayanışmadan ve yaratıcı eylemden uzak fikirlerle örülü bir dünya görüşünün derinleşmesine yol açıyor (Zuboff, 2019, s. 433-452).

Sosyal ağ platformlarında narsistik yönelimi derinleştiren diğer bir durum da, yapılan yorumların kullanıcının beğenilirliğine dair herkese açık bir belge oluşturması. Eğer kullanıcı bu belgeyi önemsiyorsa, dijital ortamdaki diğer insanların etkinliklerini sürekli izlemek ve neyin beğenilir olduğunu takip etmek zorunda. Bu zincirin yol açtığı alışkanlıklar, akademik literatürde de yer kazanan belirli bir kaygı türüne yol açıyor. FoMo (fear of missing out) olarak isimlendirilen bu kaygı, dijital ortamdaki etkinliği yeterince izleyememe endişesi olarak tanımlanıyor. Bu kaygının etkisi altına giren kişi, gün geçtikçe dijital ortamda daha fazla zaman geçirerek fiziksel ve bedensel boyuttaki gerçek ilişkilerden yoksun kaldığı bir yaşantıya mahkûm oluyor (Zuboff, 2019, s. 462-463).

Tüm bu etkinlikler sırasında kullanıcının dijital platformda harcadığı zaman ve dikkat, reklâmverenlere önceden satılmış durumda. Bu reklâmların, kullanıcının profiline ve o andaki yönelimine göre belirlendiğini önceki bölümde görmüştük. Bu algoritmaların etkisindeki kullanıcının iradesi, dengesi, kararlılık yetisi dağılıyor ve böylece önüne sıralanan reklâmların zincirine kapılıp sürüklenebiliyor. Araştırmalar dijital ortamdaki alışveriş bağımlıı̆ı̆ının ortak yaşamlarımızı etkileyen bir sorun olarak gün geçtikçe derinleştiğini gösteriyor (Vercillo, 2020, s. 111-112).

Oysa dijital platformların ortaya çıkış vaadi, insanların ilişkilerini zenginleştirmek ve güçlendirmekti. Dünyanın herhangi bir yerinden, kendi ilgi ve arayışlarına uygun sayısız kişiyle iletişim kurabilme imkânı, kullanıcıya yepyeni keşifler getiren bir yaratıcı eylem alanı açabilecekti. Böylece her kişi dünya ile ilişki kurma biçimini kendisi belirleyecekti. Kendi arayışlarına yakın duran kişilerle dostluğa dayalı dayanışmalar gerçekleştirebilecekti. Bu dayanışmaların gelişmesiyle birlikte, eşitliği ve adaleti gözeten yeni bir dünya düzeni kurulabilecekti.

Bu vaatlerin ve ümitlerin narsistik, benmerkezci, beğenilme odaklı bir sisteme doğru nasıl evrildiğini görmek için, dijital teknolojinin nasıl bir zihniyet tarafından ele geçirildiğini ve kullanıldığını fark etmek gerekiyor. Birkaç şirketin kârııı̆ını maksimize eden bu sistem, bireysel olarak da her kişinin benmerkezci bir tüketimciliği sürdürmesi sayesinde derinleşiyor. Beğenilme vazifesi ve ümidiyle oluşturulan kişisel profiller kişinin gerçek kimliğini yansıtmadığı için, gerçek dostluk ilişkilerine imkân vermiyor (Turkle, 2015). Gerçeği yansıtmayan profiller arasında 
sahnelenen sahte iletişim dramaları, gerçek dostluk ilişkilerinin ve dayanışmanın nasıl kurulacağını öğrenme fırsatını yok ediyor.

Benmerkezci ve rekabetçi yönelimin bu şekilde güçlenmesi, yaratıcı yönelimin giderek yitirilmesine yol açıyor. Yazının birinci bölümünde gözden geçirdiğimiz bulguları, yaratıcı yönelimin temel göstergelerini hatırlayalım: Kişinin etkinliğini kendi kendine değerlendirebildiği bir eylemi, kendisinin belirlediği niyetler doğrultusunda sürdürebilmesi; başarısızlık kaygısına kapılmadan, yeteneklerine uygun bir düzeyde öğrenerek ve keşfederek bir hedef doğrultusunda ilerlemesi; dikkatini bu eylemlilik üzerinde yönlendirebilmesi; benlik kaygısını bir yana bırakarak, bu eylemlilik halini en iyi şekilde gerçekleştirmek üzere çaba göstermesi. Dijital platformlardaki ilişki ortamı, bu yönelimi her açıdan örseliyor. Öncelikle kişinin davranışını başkaları tarafından beğenilme hedefi doğrultusunda şekillendiriyor. Diğer kişilerle dayanışmaya ve dürüstlüğe dayalı ilişkiler kurmasını değil, beğenileceğini umduğu sahte görüntülerle dikkat çekmesini teşvik ediyor. Bu dinamikler benlik kaygısının ve başarısızlık korkusunun yok olmasına değil, tam tersine güçlenmesine yol açıyor. Kişinin yeteneklerini ortak yaşama katkıda bulunarak geliştirmesini değil, kendisine sahte bir kimlik edinerek bu kimliği sergilemesini destekliyor. Kendi belirlediği amaçlar doğrultusunda keşfederek yol almasına değil, başkalarının beğeneceğini düşündüğü niteliklere sahip olmadığı için ümitsizliğe kapılıp körleşmesine yol açıyor.

\section{Nefret söylemi, Kutuplaştırıcı İlişki Ortamı ve Sahte Habercilik}

Kullanıının dikkatini tutsak etmek üzere kendini geliştiren yapay zekâ algoritmaları, kullanııının tutsak edilen dikkatini belirli bir hedef doğrultusunda yönlendiriyor: Dikkati kendi üzerine çekme hedefi. Böylece kişinin dikkati yaşama katkıda bulunabilecek yaratıcı eylemler için değil, benmerkezci bir tüketim arzusuna hizmet etmek için kullanılıyor.

Böyle bir çaba içine sürüklenen kişi, dijital ortamdaki sinyalleri ve verileri sürekli taramak, yorumlamak ve manipüle etmek yönünde bir yükümlülük hissediyor. Bu yükümlülük kişinin zihninde her türlü saldırıya ya da savunmaya hazır olmasını telkin eden sanal bir gereklilikler zinciri oluşturuyor. Bu zihin yapısı ve onun yol açtığı duygu hali, kişide kaygı, depresyon ve sosyal fobilerin kök salması için son derece uygun bir ortam oluşturuyor. Tehlikeleri kollamaya odaklı bu zihin yapısı, insanın evrimindeki en ilkel düzeyi temsil eden hayatta kalma refleksinin, "saldır ya da kaç" güdüsünün hükmü altında. Doğduğu andan itibaren her kişi bu refleks ve bu refleksin getirdiği her yönü kollayan dikkat yetisine sahip. Bedenimizi tehlikelere karşı korumak ve hayatta kalmak için bu hiper dikkat yeteneğine intiyacımı var. Potansiyel tehlikeleri henüz yaklaşırken algılamak, harekete geçmek gerekiyorsa harekete geçmek, eğer bu mümkün değilse de kaçmak üzere tetikte olmamı gerekiyor. Ancak, insanın gelişimi ve sonraki yeteneklerinin oluşabilmesi için, bu hiper dikkat yeteneğine bir de yoğun dikkat yeteneğinin eklenmesi gerekiyor. Yoğun dikkat yeteneği, belirli bir işe odaklanmak, araştırmak, derinlemesine tecrübe etmek 
ve öğrenmek için bir ön koşul. Ancak sosyal ağ platformlarına hâkim olan dinamikler bu platformlara bağlanan kişilerin sürekli hiper dikkat modunda kalmasına yol açarak, yoğun dikkat yeteneğinin gelişimini zorlaştırıyor (Hayles, 2012, s. 55-81). Eğer kişide yoğun dikkat yeteneği gelişmezse ya da bulunduğu ortam bu yeteneği kullanmasını engelliyorsa, kişi hiper dikkat moduna, "saldır ya da kaç" tutumuna bağlı kalıyor. Böyle bir hayatta kalma çabasına kilitli kalmak, kişinin ruh sağlığını ve dengesini olumsuz yönde etkiliyor, gelişimini sekteye uğratıyor. Sağlıklı ve dayanışmacı sosyal ilişkiler kurmasını engelliyor (Ryan ve Deci, 2018).

Sosyal ağ platformlarındaki "saldır ya da kaç" tutumuna bağımlı kullanıcıların kurduğu ilişkiler de bu zihin yapısını yansıtıyor. Oysa dijital platformların ilişkileri zenginleştirmesi; anlayışın, empatinin, yardımlaşmanın gelişimini desteklemesi elbette mümkün olabilir. Ancak bunun için, bu platformlara yön veren zihniyetin, dilin ve kültürün değişmesi gerekiyor. Bizden farklı olanı anlamaya çalıştığımız, farklılığı tehlike ve düşmanlık olarak algılamadığımız bir ortama, dile ve kültüre intiyacımız var. Bugün kullanmakta olduğumuz dijital platformlarda ise karşılıklı anlayış ve dayanışma çabasının yerine düşmanlık, kutuplaşma ve nefret söylemi hâkim. Bireysel ve ortak yaşamı iyileştirecek olan yaratıcı eylemleri, bu eylemleri ortaya koyabilecek olan zihin yapılarının gelişimini örseleyen bu yapı, insanca yaşama ve ilişki kurma intiyacımızı desteklemiyor (Morozov, 2012). Bu durumun nedenlerini anlamaya çalışmak, bu koşulların değişmesi için harekete geçmek, her birimiz için yaşamsal bir önem taşıyor.

Kutuplaşma ve nefret söylemiyle birlikte gelişen iki önemli olgu daha var; sahte haberciliğin ve komplo teorisyenliğinin yaygınlaşması. Öncelikle sahte haberciliğin neden ve nasıl yaygınlaştığını görmeye çalışalım. Sosyal ağ platformlarını işleten yapay zekâ algoritmalarının dikkati avlama hedefi doğrultusunda işlediğini görmüştük. Bu algoritmaların yürüttüğü protokollerde dürüstlük, güvenilirlik, sorumluluk, saygı, adalet gibi değerlere herhangi bir önem atfedilmiyor. Bireysel ve toplumsal yaşamın dengesi için, yaratıcı yönelimin ortaya çıkıp gelişebilmesi için birincil derece önem taşıyan bu değerler gözetilmiyor, aksine örseleniyor. Çünkü bu algoritmalar her durumda kullanıcının dikkatini avlayan içeriklere öncelik veriyor ve kullanıcının önüne bu içerikleri getiriyor. Bu algoritmalarda içeriklerin gerçeklik değerini, haberlerin doğruluk değerini dikkate alan herhangi bir mekanizma yok. Öte yandan, önceki bölümde de gördügümüz gibi, "saldır ya da kaç" tutumu doğrultusunda işleyen insan zihni, en yoğun tepkiyi tehlike mesajlarını görünce veriyor. Dolayısıyla, kişinin dikkatini en etkili biçimde avlayan sinyaller, en derin korkularını tetikleyen içerikler oluyor. Bu yüzden de yapay zekâ algoritmaları, gerçek ya da sahte olmalarını önemsemeden, kullanıcının kaygılarını tetikleyecek içerikleri seçiyor ve kullanıcının önüne bu içerikleri getiriyor. Bu sistemin içinde en fazla dikkati çeken haberler, aşırılık ve dehşet uyandırıcılık derecesi açısından gerçek haberlerin kat kat önüne geçen sahte ve uydurma haberler oluyor. Kullanıcının bu içerikleri tercih ettiğini gören yapay zekâ algoritması, daha fazla şiddet içeren ve daha fazla endişe uyandırabilecek içerikleri getirmeye devam ediyor. Bu sarmalın içine giren kullanıcı giderek daha 
kaygılı bir hale gelirken, dünyayı içinden yorumladığı perspektif de bu ruh haline ve bu içeriklere göre şekilleniyor (Rushkoff, 2011).

Öte yandan kullanıcıların dikkatini avlamak ve manipüle etmek isteyen kişiler de, olumsuz içerikli mesajlara öncelik veren bu kullanıcı eğilimini istismar etmenin yeni yollarını geliştiriyor. Manipülasyon için üretilen içeriklerin sahte olup olmadığını ve şiddet dozunu dizginleyebilecek bir mekanizma devreye girmediği için, sahte haber üretme ve yayma etkinliğine bir boyut daha ekleniyor: Komplo teorisyenliği. Nefret söylemiyle, kutuplaştırıcı ilişki biçimleriyle şekillenen dünya görüşü ve zihin yapısı, haberlerin ve içeriklerin gerçeklik değerini sorgulamak yerine, hızla inanmaya ya da reddetmeye yatkınlık getiriyor. Bu dünya görüşüyle ve zihin yapısıyla hareket eden kullanıcı, önüne çıkan sahte haberleri ve komplo teorilerini sağlıklı bir şekilde değerlendirmeden, önyargılarını daha da güçlendirmek üzere kullanabiliyor (O'Neill, 2017). Sahte haber üreticilerinin ve komplo teorisyenlerinin platforma koyduğu içerikler, bu bilgilerin doğruluğunu sorgulamadan kabul eden endişeli ve öfkeli kullanıcılar tarafından hızla yeni kullanıcılara iletiliyor. Böylece, en şiddetli ve en gerçek dışı içerikler en hızlı yayılım ve en fazla görünürlüğe erişiyor (Lanier, 2019, s. 25-37).

Bu mekanizma, dijital platformlar ile yakından veya uzaktan ilişkili olan her birimizin yaşamını etkileyen, çok ciddi sorunlara yol açıyor. Zira, ortak yaşamımızın sağlıklı düzeyde sürmesi için ön koşul olan eleştirel düşünce biçimleri ve ortak referans sistemleri sahneden çekiliyor. Gerçek diye bir şeyden söz edilemeyeceğine, ortaya atılan tüm fikirlerin gerçeklik açısından eşit değere sahip olduğuna dair bir inanç söz konusu. (Bridle, 2019, s. 196-221). Bu inanç, ortak ve dayanışmacı yaşam çabalarını anlamsız kılıyor, güvene dayalı dostluk ilişkilerini ortadan kaldırıyor, kişileri kaygılı ve ümitsiz bir yalnızlık haline mahkûm ediyor (Freitas, 2019).

İnsanın diğer insanlara karşı güven ve sevgi duyma yetileri ancak zamanla gelişip köklenebilen, gelişebilmeleri için de hem kişinin niyet ve çabasını, hem de bu çabayı destekleyen bir ortamı gerektiren yetenekler. Bu yetenekler ömür boyu süren bir sabır, irade ve azım sayesinde elde edilebiliyor. Yaratıcı eylem halini sürdürebilmek için de kişinin diğer kişilere güven ve sevgi duyabilmeye intiyacı var. Bu güven ve sevgi sayesinde düşünce ve eylemlerini ortak yaşamı iyileştirmek üzere yönlendirme isteğini ve iradesini buluyor. Bu çaba sırasında gelişen yetenekleri doğrultusunda, eleştirel düşünme imkânını ve alışkanlığını elde ediyor (Ryan ve Deci, 2018). Ancak dijital platformların günümüzdeki işleyiş dinamikleri, insanlar arasındaki sevgi ve güvenin gelişimini desteklemiyor; aksine eritip yok ederek, yaratıcı düşünce ve eylem halinin, eleştirel düşünce yeteneğinin ortaya çıkmasını ve gelişmesini engelliyor.

\section{Sorunu Belirlemek ve Yaratıcı Çözümler Geliştirmek}

İçinde bulunduğumuz bu durumu dijital teknolojinin getirdiği koşulların kaçınılmaz bir sonucu olarak değerlendirmeye yatkın olan teknolojik determinizm 
sözcüleri, 2000 yılı sonrasında doğan kullanıcıları "dijital yerliler" adıyla tanımlıyor (Zuboff, 2019, s. 447). Bu teknolojik determinizm sözcülerinin temel yanılgısı, yaşanan durumu teknolojik gelişmelerin kaçınılmaz bir sonucu olarak yorumlamak. Oysa insanın yaratıcı düşünce ve eylem yeteneklerini örseleyen bu dijital ortam teknolojik gelişmelerin değil, onlara yön veren zihniyetin eseri. Bu zihniyet insanın tüm davranışlarını belirlenebilir, öngörülebilir, yön verilebilir, dolayısıyla alınıp satılmak üzere manipüle edilir kılmak istiyor. Bu yüzden de dijital ortamda varlık gösteren bireylerin iç dünyasını kolonize etmek, sömürgeleştirmek üzere çalışıyor. Bu açıdan bakınca, 2000 yılı sonrası doğan kuşakların "dijital yerliler" olarak tanımlanması da yeni bir anlam kazanıyor. Dijital yerliler, onları kolonize etmek isteyen zihniyetin kurallarını gözü kapalı kabullenmiş, onlara uyum sağlamış, bu sistemin dilini ve kültürünü kendi dili ve kültürü olarak benimsemiş bir kuşak olarak görülebilir. Ancak bu durum, bu kuşağın potansiyel olarak taşıdığı yaratıcı eylemliliğin, dayanışmacılığın, insana yaraşır erdemlerin ve düşüncelerin yok sayılması anlamına gelmemeli. Bunun için de, yaratıcı düşünce ve eylemin dijital ortamdaki protokollere kurban edilmediği, dayanışmanın ve birlikte keşfetmenin en önemli insanî yetenekler olarak kabul gördüğü ve geliştirildiği bir dil ve kültür yaratmamı gerekiyor.

Bunun için, öncelikle sorunu adlandırmaya ihtiyacımız var. Sorun, sosyal ağ platformlarını elinde tutan bir avuç teknoloji şirketinin kârıı̆ığını arttırmak uğruna milyarlarca insanın zihnini, iradesini ve yaratıcı eylem yeteneğini sömüren, mekanikleştiren, tutsak eden ekonomik sistem. Bu sistem dijital teknolojinin sağladığı tüm imkânları bu amaç için kullanıyor. Dünyanın en iyi eğitimli, en yetenekli kişilerini dünyanın geri kalanını sömürgeleştirme projesinde çalıştırmak üzere istihdam ediyor. Bu eğitimli ve yetenekli kişiler, ortak yaşamımızın önünde duran gerçek sorunları çözmek üzere çalışmıyor. Zehirli enerji kaynaklarının yerine sürdürülebilir enerji kaynakları keşfetmek, toprağı ve atmosferi zehirlemeyen tarım yöntemleri geliştirmek, dünyadaki olağanüstü gelir eşitsizliğini dengelemek, milyarlarca insanın ölümüne yol açan açlık, kıtlık, hastalık sorunlarına çare bulmak, milyarlarca insanın eğitim intiyaçlarına çözüm geliştirmek için, öncelikle bu temel sorunla yüzleşmemiz gerekiyor. Yaratıcı düşünce ve eylem yeteneklerimizi bu sömürgeleştirici zihniyetin etkisinden kurtarmaya ve bu zihniyetin dinamikleri karşısında yaratıcı çözümler geliştirmeye ihtiyacımız var.

Dikkatimizi, irademizi ve zihnimizi tutsak alan dijital platformlar, teknolojinin kaçınılmaz bir sonucu değil. Dijital teknolojinin yaratıcı düşünce ve eylem imkânlarımıza hizmet etmesini sağlayabiliriz. Ancak bunun için öncelikle, teknolojiye nasıl bir zihniyetin yön vermesini istediğimize karar vermemiz gerekiyor. Bu sistemin dengesizliklerini, bu sistemin en temel değerlerimize nasıl zarar verdiğini fark ettikçe bu sistemin değişmesi için dayanışmaya girebiliriz. Bugüne kadar oluşmasına hep birlikte katkıda bulunduğumuz bu sistem değişecekse, bizim talebimiz ve irademizle değişecek. Yaratıcı düşünce ve eylemlilik halimiz sayesinde değişecek. Bunun için öncelikle dikkatimizi, irademizi ve yaratıcı eylemliliğimizi dijital platformların işgalinden kurtarmak ve korumakla işe başlamalıyız. Böylece serbest kalan dikkatimiz ve irademiz, içsel değerlerimize ve niyetlerimize hizmet 
edebilir, yaratıcı ve dönüştürücü eylemlere yol açabilir. Her birimizin ortaya koyduğu yaratıcı eylemler ortak yaşam alanımızı dönüştürmek üzere, dayanışma içinde gerçekleşebilir. Bu dayanışma, sömürü sistemine yol açan zihniyetin etkisinden kurtulmak ve korunmak isteyen yeni kişilere destek olabilir. "Dijital yerliler" tanımına hapsedilmek istenen genç kuşakların da can vereceği yeni iletişim ağları oluşturabilir. Her birimizi benmerkezci bir tüketimciliğe mahkûm etmek üzere işleyen sömürücü zihniyetten ancak bu şekilde özgürleşebiliriz.

Bu sistemin yol açtı̆̆ı sorunları kavrayan ve seslendiren kişilerin sayısı çoğaldıkça, dijital platformlardaki işletim dinamiklerinin değişmesi için yeterli irade ve talep oluşabilecektir. Bu talebin oluşması durumunda, kullanıcılara intiyaç duydukları hizmeti verdiğini iddia eden dijital platform yöneticileri de protokollerini değiştirmek yönünde bir baskı hissedebilir. Eğer köle ticareti, organ ticareti, çocuk istismarı ve şiddete dayalı zorbalık kabul edilmemesi gereken insanlık suçlarıysa, dijital platformların bu modelde sürdürülmesi de kabul edilmemesi gereken bir insanlık sorunudur. Bu sistemin ortak yaşamımızı bu şekilde sömürmesine göz yumduğumuz sürece, bu insanlık sorununa biz de katkıda bulunuyoruz. Bu sorunun çözümüne katılmak için en uygun zaman ve mekân, şimdi ve burası. Yaratıcı düşünce ve eylem imkânlarımızın harekete geçirilmek üzere bizi beklediği tek zaman ve mekân.

\section{Kaynakça}

Alter, A. (2018). Irresistible: the rise of addictive technology and the business of keeping us hooked. New York, NY: Penguin.

Andreassen, C. S. (2015). Online Social Network Site Addiction: A Comprehensive Review. Current Addiction Reports, 2(2), 175-184. doi:10.1007/s40429-0150056-9

Barak, A. (Ed.) (2008). Psychological aspects of cyberspace: Theory, research, applications. UK: Cambridge University Press.

Bridle, J. (2019). New dark age: Technology and the end of the future. London: Verso.

Bueno, C. C. (2017). The attention economy: labour, time and power in cognitive capitalism. London: Rowman \& Littlefield.

Carr, N. G. (2011). The shallows: what the Internet is doing to our brains. New York, NY: W.W. Norton.

Csikszentmihalyi, M. (1996). Creativity: Flow and the psychology of discovery and invention. New York, NY: Harper Perennial.

Csikszentmihalyi, M. (2014a). Applications of flow in human development and education: The collected works of Mihaly Csikszentmihalyi. Dordrecht: Springer. 
Csikszentmihalyi, M. (2014b). Flow and the foundations of positive psychology: The collected works of Mihaly Csikszentmihalyi. Dordrecht: Springer.

Csikszentmihalyi, M. (2014c). The systems model of creativity: The collected works of Mihaly Csikszentmihalyi. Dordrecht: Springer.

Foroohar, R. (2019). Don't be evil: How big tech betrayed its founding principles - and all of us. New York, NY: Currency.

Freitas, D. (2019). The happiness effect: How social media is driving a generation to appear perfect at any cost. New York, NY: Oxford University Press U.S.

Eubanks, V. (2019). Automating inequality: How high-tech tools profile, police, and punish the poor. New York, NY: Picador, St. Martin's Press.

Galloway, S. (2018). The four: the hidden DNA of Amazon, Apple, Facebook, and Google. London: Corgi Books.

Hayles, N. K. (2012). How we think: Digital media and contemporary technogenesis. Chicago: University Of Chicago Press.

Jackson, M. (2018). Distracted: Reclaiming our focus in a world of lost attention. New York: Prometheus Books.

Karwowski, M., ve Kaufman, J. C. (Ed.) (2017). The creative self: Effect of beliefs, self efficacy, mindset, and identity. London: Elsevier.

Kuss, D. J., ve Griffiths, M. D. (2011). Online Social Networking and Addiction-A Review of the Psychological Literature. International Journal of Environmental Research and Public Health, 8(9), 3528-3552. doi:10.3390/ijerph8093528

Kuss, D., ve Griffiths, M. (2017). Social Networking Sites and Addiction: Ten Lessons Learned. International Journal of Environmental Research and Public Health, 14(3), 311. doi:10.3390/ijerph14030311

Lanier, J. (2010). You are not a gadget: A manifesto. London: Penguin.

Lanier, J. (2019). Ten arguments for deleting your social media accounts right now. NY: Picador.

Noble, S. U. (2018). Algorithms of oppression: How search engines reinforce racism. New York, NY: New York University Press.

O'Neil, C. (2017). Weapons of math destruction: How big data increases inequality and threatens democracy. UK: Penguin Random House.

Morozov, E. (2012). The net delusion: The dark side of internet freedom. New York, NY: PublicAffairs.

Richards, R., ve Csikszentmihalyi, M. (2007). Everyday creativity and new views of human nature: Psychological, social, and spiritual perspectives. Washington, DC: American Psychological Association.

Rushkoff, D. (2011). Program or be programmed: Ten commands for a digital 
age. Berkeley, CA: Counterpoint.

Ryan, R. M., ve Deci, E. L. (2018). Self-determination theory: Basic psychological needs in motivation, development, and wellness. New York, NY: The Guildford Press.

Turkle, S. (2016). Reclaiming conversation: The power of talk in a digital age. New York, NY: Penguin Books.

Vartanian, O., Bristol, A. S., ve Kaufman, J. C. (Ed.) (2016). Neuroscience of creativity. Cambridge, MA: The MIT Press.

Vercillo, K. (2020). Internet addiction. Santa Barbara, CA: Greenwood, ABC-CLIO, LLC.

Williams, J. (2018). Stand out of our light: freedom and resistance in the attention economy. Cambridge, UK: Cambridge University Press.

$\mathrm{Wu}, \mathrm{T}$. (2016). The attention merchants: the epic scramble to get inside our heads. New York, NY: Knopf.

Zuboff, S. (2019). The age of surveillance capitalism: The fight for a human future at the new frontier of power. New York, NY: PublicAffairs. 